\title{
MÁSCARA E HOMEM NEGRO: \\ ENTRE O CONTÁGIO E O RACISMO EM \\ UM REGIME NECROPOLÍTICO
}

\author{
MÁSCARA Y HOMBRE NEGRO: ENTRE CONTAGIO $\Upsilon$ RACISMO \\ EN UN RÉGIMEN NECROPOLÍTICO \\ MASK AND BLACK MAN: BETWEEN CONTAGION AND RACISM \\ IN A NECROPOLITICAL REGIME
}

\section{Lucas Gabriel de Matos Santos ${ }^{1}$ e Rosa Pedro ${ }^{1}$}

${ }^{1}$ Universidade Federal do Rio de Janeiro, Rio de Janeiro/RJ, Brasil

\begin{abstract}
RESUMO: Com a declaração da OMS de uma pandemia do novo coronavírus, novos hábitos e medidas de segurança sanitária passaram a ser elaboradas e adotadas a fim de conter o rápido contágio. No entanto, as medidas estipuladas, concebidas a partir da lógica ocidental, protegem um ser humano abstrato, desconsiderando as multiplicidades que nos diferenciam, em especial nos países do Sul Global. Neste artigo serão analisadas as articulações entre uma medida específica - o uso de máscaras para proteção da contaminação - e corpos singulares, de uma parcela da população exposta a diversas vulnerabilidades sociais e marcada pela desigualdade racial que agrava a necessidade de proteção na pandemia. As máscaras junto aos corpos de homens negros, podem produzir mais vulnerabilidade, medo e morte. Efeitos diferentes da proteção pretendida, tendo em vista o regime necropolítico associado ao acúmulo de desigualdades e racismo, marcas estruturais características da colonialidade experienciada em cidades como o Rio de Janeiro.
\end{abstract}

PALAVRAS-CHAVE: Pandemia; Máscara; População negra; Racismo; Necropolítica.

RESUMEN: Con la declaración de la OMS de una nueva pandemia de Coronavirus, se comenzaron a desarrollar y adoptar nuevos hábitos y medidas de seguridad sanitaria para contener el rápido contagio. Sin embargo, las medidas estipuladas, concebidas con base en la lógica occidental, protegen a un ser humano abstracto, sin tener en cuenta las multiplicidades que nos diferencian, especialmente en los países del Sur Global. En este artículo, se analizarán los vínculos entre una medida específica (el uso de máscaras para proteger contra la contaminación) y los cuerpos singulares de una porción de la población expuesta a diversas vulnerabilidades sociales y marcada por la desigualdad racial que agrava la necesidad de protección en la pandemia. Las máscaras junto a los cuerpos de los hombres negros pueden producir más vulnerabilidad, miedo y muerte. Diferentes efectos de la protección pretendida, ante el régimen necropolítico asociado a la acumulación de desigualdades y racismo, marcas estructurales propias de la colonialidad vivida en ciudades como Río de Janeiro.

PALABRAS CLAVE: Pandemia; Máscara; Población Negra; Racismo; Necropolítica.

ABSTRACT: Since WHO's statement of a pandemic of the new coronavirus, new habits and health security methods have been developed and adopted in order to contain the contagion spread. However, the stipulated methods are mainly conceived from a Western logic. They protect an abstract human being, disregarding the multiplicities that differentiate us, especially in the countries of the Global South. This paper analyzed the articulations between a specific method the use of masks to protect against contamination - and singular bodies of part of the population that are exposed to different social vulnerabilities and marked by racial inequality. The masks that partially cover the face, when coupled with the bodies of black people, produce vulnerability, fear and death. These are different effects from the intended protection by the use of masks, owing to the necropolitical regime associated with the accumulation of inequalities and racism, structural conditions that are characteristics of the coloniality experienced in cities such as Rio de Janeiro. KEYWORDS: Pandemics; Mask; Black population; Racism; Necropolitics. 


\section{Introdução}

Nove de abril de 2020. Eu e Juliana nos dirigimos a um bairro a pouco mais de $30 \mathrm{~km}$ de onde moramos para comprar cestas básicas e trazer para a comunidade religiosa de que fazemos parte. A comunidade distribui cestas básicas para famílias que empobreceram diante da crise econômica, consequência da pandemia de Covid-19. Naquela manhã, Juliana me buscou em casa com sua Ford Ranger XL - um carro com porte de caminhonete, que chama a atenção - e me levou até o centro da cidade, a fim de pegar máscaras de pano que havia encomendado com uma costureira, mãe de uma amiga. Máscaras que serviriam como bloqueio físico para proliferação e contágio do vírus. As máscaras eram personalizadas com símbolos e cores inspirados nos países africanos. Seguimos viagem pela Avenida Brasil - via expressa que liga o centro da cidade do Rio de Janeiro às regiões norte, oeste e a outros municípios da Baixada Fluminense.

Já próximos do nosso destino, ainda na Avenida Brasil, foi nos indicado sair da via expressa pela lateral à direita, entrar à esquerda em um túnel, viramos à esquerda novamente e fazermos o retorno. Já tínhamos visto nosso destino, mas nossa viagem foi interrompida por um assombro. Parados no semáforo vermelho, pouco mais de 10 metros adiante, havia um carro da Polícia Militar parado. Após liberar o motorista à frente, os dois policiais, com fuzis, farda preta e capacete, olham em nossa direção enquanto caminhavam para entrar na viatura. Subitamente param e sustentam o olhar. Poderia ser um movimento banal se não tivéssemos consciência do conjunto que os policiais olhavam: não eram só duas pessoas em um carro, eram duas pessoas negras, uma mulher com pele mais retinta e de tranças, um homem com pele mais clara e cabelo raspado. Em um carro do porte de uma caminhonete que chama a atenção. Ambos de máscara. Coração acelerado, medo. Eu não me movia, e sentia que Juliana também não. Os policiais continuam olhando. O semáforo abre. Passamos ao lado deles sentindo os olhares nos acompanhando enquanto olhávamos para frente. "Maldito dia pra usar máscara", ela disse. Eu concordei. ${ }^{1}$

$\mathrm{O}$ ano de 2020 carrega um acontecimento capaz de descontinuar uma certa "normalidade" e alterar alguns rumos. Passamos todos por uma pandemia e é difícil descrever como o mundo e os fluxos que o sustentam mudaram e continuam a mudar. Um vírus descoberto em dezembro de 2019, em Wuhan, província chinesa, alcançou os cinco continentes em menos de 4 meses. Todo e qualquer número que acompanhe essa escrita caduca imediatamente, podendo ser substituído por outros que traduzem a mesma intensidade. Faltam-nos código e dimensão para compreender o que é viver em pandemia.

São muitos números. Qualquer dado é insuficiente. Números de mortos, infectados, pessoas infectadas assintomáticas, curadas, corpos sem diagnóstico, famílias sem funerais, corpos sem cova, leitos na Unidades de Terapias Intensivas, respiradores. A distância segura a se manter das pessoas, o tempo necessário para lavar as mãos, o tempo em que o vírus fica em superfície de metal, papelão, plástico, roupa. As medidas de segurança se multiplicam e favorecem enquadramentos. Não saia de casa se não for necessário. Tire as roupas que usou na rua antes de entrar em casa, tire os sapatos, lave as mãos, as roupas, as compras do mercado, as sacolas das compras do mercado, limpe o chão que pisou, não toque, não aperte o botão do elevador com o dedo, não vá de elevador, não aperte o botão 
da máquina do cartão, não segure dinheiro. Bloqueie seu rosto. Se espirrar ou tossir, proteja com o braço. Se um membro de sua família estiver contaminado, isole-o em um cômodo da casa. Redobre o cuidado com pessoas que estejam no grupo de risco. Use máscaras. Algumas podem ser lavadas, outras são descartáveis. Não tire as máscaras antes de lavar as mãos e, ao tirá-las, lave novamente as mãos. Novamente, não saia de casa. Use máscaras. Ufa!

Em poucos meses, somos inundados por novas práticas necessárias de segurança e saúde. Como toda medida e parâmetro universalizantes, ao entrarem em contato com um mundo caracterizado pela multiplicidade e desigualdade, evidenciam choques e desajustes. Novas experiências advindas de um problema recorrente, do ímpeto de ser globalizado e universal. O vírus, altamente contagioso, cria as ligações e se conecta pela similaridade de quem o carrega. As medidas de segurança não. Essas protegem um sujeito universal, sem discutir as relações de alteridade que existem entre quem se protege com as medidas e para quem essas medidas não são suficientes. Quem precisa de outras medidas para se proteger neste novo mundo, e quem pode ficar mais vulnerável em outros aspectos, apesar delas.

Como ressalta Preciado (2020), os protocolos e práticas de administração da vida e da morte postos em cena pela Covid-19 desenham os contornos de uma "nova subjetividade", que precisará ser afirmada para sobreviver ao vírus. Esse "novo sujeito", assim produzido, "não tem pele, é intocável, não tem mãos. ... Não se reúne nem se coletiviza. É radicalmente indivíduo. Não tem rosto, tem máscara” (Preciado, 2020, p. 5). Não surpreende que esse sujeito se produza no contexto de uma racionalidade neoliberal, que investe no indivíduo como gestor de si e de sua saúde, apropriando-se das diferentes ordens da vida, até chegar a configurar o modo mais íntimo da existência (Dardot \& Laval, 2016; Rose, 2019).

A partir dessas medidas sanitárias de segurança universalizantes, também se produz um certo tipo de comunidade que converge para um ponto central: proteger-se do vírus, conforme as prescrições. Nessa comunidade, configura-se uma hierarquia entre corpos que podem fazer parte dela e os considerados perigosos, pois colocam a própria comunidade em risco, devendo ser excluídos "em um ato de proteção imunológica" (Preciado, 2020, p. 3). É importante, portanto, destrincharmos as maneiras pelas quais essa nova comunidade opera sua imunização. Para além da identificação de que corpos devem ser considerados perigosos à manutenção da comunidade, é preciso explicitar como isso é feito: quais mecanismos, práticas e ações são utilizadas, ou atualizadas, para proteção da comunidade e como são operacionalizadas ao entrar em contato com corpos que não podem fazer parte da comunidade.

Neste manuscrito, abordaremos uma medida de segurança específica em tempos de pandemia: o uso de máscaras que cobrem parcialmente o rosto, justificado para fins de prevenir o contato de áreas da mucosa (nariz e boca) com o exterior. Seu uso, inicialmente restrito aos profissionais de saúde, foi posteriormente recomendado a quem potencialmente tivese sintomas da doença a fim de proteger os não infectados, até ser generalizado em algumas cidades brasileiras, sob pena de multa. Estudos indicam que o uso frequente das máscaras, combinado a restrições pontuais de circulação, impedirá que novas ondas de contaminação aconteçam (Stutt et al., 2020).

No entanto, em países latinoamericanos, que acumulam desigualdades estruturais, marcados por processos violentos, como colonialismo e escravização, há outros efeitos a serem considerados (Galindo, 2020; Preciado, 2020; Quijano, 1992,). Além das vulnerabilizações a que a população negra está submetida a partir da assimétrica distribuição dos aparatos públicos de saúde, da necessidade de sair do isolamento para prestar serviços informais, das más condições de saneamento e moradia, há uma política de segurança pública 
com intensa violência policial, que prossegue com operações nos territórios favelados em tempos de pandemia. As diferentes vulnerabilizações que reatualizam o genocídio da população negra são também operadas pelos agentes armados do Estado, tendo como alvo historicamente definido como perigoso, o homem negro.

O uso de máscaras em territórios em que o racismo faz parte do modo de organização da sociedade produz efeitos outros, desconhecidos para aqueles que propõem as máscaras como cuidado sanitário universal. A máscara, acoplada ao corpo negro, pode trazer o medo da morte. Seu esquema epidérmico racial, aprendido através do racismo cotidiano, indica a este corpo que, para se proteger, ele precisa tirar a máscara. A Covid-19 expõe como é profunda e irracional a desigualdade racial em que estamos inseridos.

Pretende-se, neste artigo, explorar as relações presentes entre um objeto aparentemente a-político - a máscara -, que pretensamente materializa a "neutralidade" de uma técnica de segurança sanitária, e corpos totalmente atravessados de políticas de morte. Para os corpos de homens negros e pobres, a máscara pode produzir mais morte do que lhes garantir a proteção desejada, inclusive produzindo políticas mortificadoras. É preciso entender então como esses objetos, articulados a certos corpos, produzem efeitos tão distintos.

\section{Sobre a não neutralidade das máscaras}

Acompanhar as conexões que se produzem a partir da presença de um não humano, neste caso a máscara, não é trivial e permite evidenciar a tessitura sóciotécnica ${ }^{2}$ dessa rede. Os pontos que se ligam a esse objeto nestes tempos de pandemia a todo momento se modificam. A cada semana há novas orientações, inclusive sobre as máscaras, para dar conta dos pontos que se movimentam junto às novas políticas sanitárias.

Os movimentos dos fluxos em torno das medidas sanitárias postos em cena pelo novo coronavírus subvertem os prescritos indicados ao uso de máscaras. Isso porque esses prescritos foram produzidos a partir de uma ordem coletiva de imunidade, mas o uso de máscaras foi apropriado em outro ordenamento. Mais precisamente, a diretriz inicial da Organização Mundial de Saúde (OMS) ${ }^{3}$ indicava o uso de máscaras cirúrgicas e descartáveis para profissionais de saúde, pessoas infectadas ou que pudessem ter tido contato com pessoas com Covid-19. As indicações do órgão global se sustentavam pelo risco de desabastecimento nos estoques desses insumos a partir de seu uso exagerado, o que poderia comprometer a saúde dos que precisariam usá-las, e ainda pela falta de estudos científicos que indicassem que o uso de máscaras de modo generalizado seria capaz de diminuir o potencial de contágio.

O que vimos acontecer, no entanto, foi a apropriação dessa diretriz para uma proteção "individual”, indicando a inserção do uso da máscara na maquinaria neoliberal na qual somos constituídos desde nossas práticas mais cotidianas. Nessa racionalidade neolberal, a lógica do valor é ampliada para todos os âmbitos da vida (Dardot \& Laval, 2016), produzindo uma espécie de utilitarismo individual, que se produz ainda às custas dos princípios comunitários e coletivos, direcionando nossas subjetividades a uma valorização dos meios individuais de proteção e saúde.

Assim, em tempos em que o indivíduo é amplamente responsabilizado por sua posição e trajetória social econômica, assim também o será por sua proteção. A preocupação da OMS quanto aos usos exagerados das máscaras já sinalizava uma antecipação à lógica 
medicalizante dos modos de prevenção, o que também se pode ver em outros modos de garantia de saúde e higiene individualizados - como no crescimento de $6.500 \%$ da procura por álcool gel, por exemplo (Gaglione, 2020).

Este ímpeto individualizante está em desacordo com as tentativas que visam a garantia da saúde coletiva e universal. Esse universal, segundo o princípio de equidade do Sistema Único de Saúde (SUS), busca abarcar também os que não podem se valer de medidas individualizantes de proteção. É nesse sentido que se procura garantir o abastecimento de EPIs para os profissionais de saúde, bem como a defesa do SUS, única alternativa viável de garantir a segurança sanitária a todos, atentando para as desigualdades existentes e agindo sobre elas - e que vem sendo sucateado a fim de dar espaço às redes privadas de plano de saúde. Vale destacar que o princípio do SUS de equidade e a universalidade das ações não obedecem ao ímpeto universalizante neoliberal. O universal do SUS é garantir saúde a todos. O universal neoliberal consiste em enquadrar todos no 'Um', aquele que pode ter saúde, descartando os que não conseguem alcançar tal condição.

Estudos começaram a indicar que o uso generalizado de máscaras, inclusive as não descartáveis, teria efeitos substanciais para a desaceleração do contágio comunitário (Howard et al., 2020). Assim, o uso de máscaras "caseiras" surge como provável medida de prevenção, sendo sua produção e uso incentivada pelos Estados. A partir de então, a adoção de máscaras de tecido para pessoas que não fossem profissionais da saúde passou a ser indicada e viabilizada no Brasil pela Agência Nacional de Vigilância Sanitária (ANVISA, 2020). O impulso individual de proteção ainda existe, no entanto passa a estar articulado a outras cadeias de processos. Mulheres que não tinham de onde tirar o sustento passaram a providenciar máscaras para toda a população, o que significou a geração de renda para algumas famílias. O uso das máscaras em locais públicos passa a servir não para a proteção de si, mas para a proteção do outro, em caso de circulação de pessoas assintomáticas portadoras do vírus, ou mesmo pré-sintomáticas.

Trazemos essas considerações para evidenciar as conexões tecidas em torno de um objeto, bem como suas reverberações políticas. A máscara, como objeto político, movimenta uma rede extensa e heterogênea, ainda que não possamos ver ou sentir todos os seu movimentos, daí a necessidade de acompanhar os caminhos que ela faz e o que a ela se conecta, produzindo efeitos - proteção, geração de renda, por exemplo. É nesse sentido que salientamos a importância de compreender que os objetos não são neutros, eles têm política. Dito de outro modo, não há como conceber um objeto que não traga em si uma rede de escolhas e posicionamentos políticos, e não há como conceber a política ou a sociedade como não sustentada por objetos técnicos. Nos termos da Teoria Ator-Rede, tecnologia e sociedade não são exteriores uma à outra, mas compõem um "tecido inconsútil”, o tecido sóciotécnico. Isto possibilita perceber, nos objetos técnicos, não apenas o fato de que foram concebidos em um determinado contexto social, mas sobretudo sua potência de tecer o social e a política, modelando os sujeitos, os corpos e a vida.

Essa perspectiva nos permite tomar os objetos técnicos fora de uma chave bom/mau, sem, contudo, considerá-los “neutros”. Defendemos a importância de localizar a produção desses objetos e acompanhar sua trajetória, atentando para sua capacidade de agência, de nos fazer-fazer (Latour, 2006), de movimentar a rede. Essa atenção à agência dos objetos não significa tomá-los como determinantes de nossas ações - o que implicaria em uma visão reificadora ou fetichista da tecnologia - mas justamente apontar para os vínculos (Latour, Rifiotis, Petry, \& Segata, 2015), cuja qualidade podemos apreender de modo situado. 
Recusamos análises desencarnadas, que se pretendem neutras, na medida em que podem implicar ausência de responsabilidades e limites. Tomar os objetos como neutros invisibiliza a potência dos vínculos de criar mundo e, consequentemente, a participação desses não-humanos no regime biopolítico contemporâneo.

Reiteramos: a máscara não é um objeto neutro, é um artefato político. Sua articulação com sujeitos humanos, com diferentes corpos, em diferentes situações, produzirá diferentes efeitos (Latour, 2008). Assim é na pandemia: a máscara tem um sentido de proteção de um corpo passível de contaminação, funcionando como um bloqueio físico. No entanto, propomos que o acoplamento da máscara a corpos concretos produz efeitos diversos. Especificamente referimo-nos aqui à sua associação ao corpo negro, um corpo marcado pelo racismo, pela vulnerabilização sistêmica, pelo imaginário social atrelado ao negro como representação do perigo e pelas políticas de morte.

\section{O corpo vulnerabilizado pelo contágio}

A pretensão de neutralidade da técnica de segurança sanitária some ao entrar em contato com as multiplicidades, principalmente no contexto específico brasileiro, marcado por acúmulos de desigualdade. Alguns indicadores podem nos ajudar a compreender essas desigualdades. Segundo o censo 2010 produzido pelo Instituto Brasileiro de Geografia e Estatística (IBGE), 56\% da população brasileira se considera preta ou parda. Este primeiro dado deve servir de parâmetro para todos os outros, onde seria razoável indicarmos que, vivendo em uma democracia racial, os próximos dados a serem apresentados não seriam tão díspares.

No entanto, os dados mostram que, na educação, em 2018, a taxa de analfabetismo de autodeclarados negros (maiores de 15 anos) chegou a $9,1 \%$ enquanto a de brancos é 3,1\%. Sobre a taxa de ocupação no ensino superior, entre as pessoas de 18 a 24 anos, $55,6 \%$ são negras, enquanto que próximo a $79 \%$ são brancos. O indicador salienta ainda que a taxa de ocupação no ensino superior implica em retornos salariais muito maiores (IBGE, 2019).

Se levarmos em conta a classe social por renda, enquanto $16,4 \%$ da população branca estava entre os $10 \%$ com maiores rendimentos, apenas $4,7 \%$ da população preta ou parda encontrava-se na mesma posição. De modo análogo, dos 10\% com menores rendimentos, 13,6\% era preta ou parda e apenas 5,5\% branca. Este dado é reafirmado se levarmos em conta os que estão em extrema pobreza, sendo $32 \%$ pretos e pardos, e $15 \%$ brancos. (IBGE, 2019)

A pobreza do Brasil é regionalmente diferenciável. Entre a parcela da população que possui renda mensal até um quarto do salário mínimo, $25 \%$ estão no nordeste, $22 \%$ no Norte, $7 \%$ no Sudeste, $7 \%$ no Centro Oeste e 5\% no Sul (Síntese, 2018). De modo semelhante, acontece a distribuição racial no Brasil. 79\% da população da região Norte é de não-brancos, seguida pela região do Nordeste com $73 \%$. A região Centro-Oeste possui $62 \%$. As regiões Sudeste e Sul possuem menos negros, com 48\% e 25\%, respectivamente. (IBGE, 2019)

A despeito desssa distribuição, o SUS, ao propor a universalidade e equidade como princípios, torna-se a política pública com maior importância no desempenho de garantia de justiça social frente às desigualdades. Ao analisarmos os dados de classe e raça em conjunto, fica evidente o que a Organização das Nações Unidas (ONU) aponta: quase 80\% da população negra depende do SUS (ONU, 2017). 
A necessidade de monitoramento da política é expressa na desigualdade da distribuição de componentes técnicos de saúde. A distribuição de leitos de UTI obedece uma ordem inversa à distribuição da população negra e pobre, maiores usuários do serviço. Enquanto a região Norte e Nordeste possuem 1,23 e 1,35 leito de UTI para 10.000 habitantes respectivamente, as regiões Sul, Sudeste e Centro Oeste possuem mais de 2 leitos (Costa, 2020).

A dependência a um sistema de saúde pública propositalmente sucateado é um fator que se soma a outras complexidades, produzindo vulnerabilidade ao corpo negro ao se deparar com uma pandemia. A primeira vítima de Covid-19 do estado do Rio de Janeiro aponta por onde as vulnerabilidades se manifestam: ela prestava serviços de limpeza a uma família moradora do Leblon (bairro com o metro quadrado mais caro do Brasil), que tinha voltado recentemente da Itália com diagnóstico positivo para Covid-19. A família estava em tratamento domiciliar e isolamento social, mas não avisaram nem dispensaram a empregada dos seus serviços. Após um dia de serviço, a empregada volta para casa, passa mal e se dirige ao hospital de Miguel Pereira, vindo a falecer. Ainda que não seja registrado o componente raça/cor deste caso, os marcadores sociais e de vulnerabilidade permitem aproximarmos a população negra à vítima. As mulheres negras são a maioria na ocupação do serviço de limpeza de casas e que mora em bairros da Zona Norte do Rio de Janeiro.

Os indicadores anteriores sustentam a afirmação de uma racialização nos efeitos pandêmicos do contágio de Covid-19 no Brasil, ao invés de uma pretensa democratização do contágio. O Núcleo de Operações e Inteligência em Saúde (NOIS), publicou no dia 27/05/2020 uma análise apontando a variação da taxa de letalidade a partir de dados socioeconômicos, inclusive a partir de uma racialização dos dados. Entre brancos, a taxa de letalidade é $38 \%$, enquanto entre negros $55 \%$. Esta diferença se repete em todas as faixas etárias. A escolaridade também se apresenta como um analisador. Entre as pessoas com nível superior, a letalidade é de $22,5 \%$, enquanto entre aquelas sem escolaridade a letalidade é de $71 \%$. Este dado é diretamente influenciado pela diferença de renda. Em todos os níveis de escolaridade, a população negra é a mais vitimada (Batista et al., 2020).

A racialização dos dados nos sistemas de saúde pública é uma medida historicamente pautada pelo Movimento Negro. Até 8 de maio, dentre as 9.847 mortes registradas, 35\% foram declaradas de pessoas pretas ou pardas, $34 \%$ foram declaradas brancas e $29 \%$ não tiveram os dados de raça/cor registrados. Um mês antes, os dados correspondiam respectivamente a $22 \%$, $40 \%$ e $36 \%$. Este é um exemplo de muitos registros da subnotificação que acompanham os dados da pandemia, prejudicando a melhor visualização da situação da população negra (Sardinha, Botelho, \& Carvalho, 2020) ${ }^{4}$. Nos dados anteriormente utilizados pelo NOIS, $36 \%$ dos óbitos foram registrados como negros, $27 \%$ de brancos e $34 \%$ tiveram o campo raça não declarados.

As subnotificações também caminham por outros meios. As localidades com maior quantidade de pessoas negras são as mais atingidas, mas esses números são quantificados em função de uma separação em bairros, ignorando as favelas existentes, por exemplo, no Rio de Janeiro, ou mesmo comunidades quilombolas e indígenas presentes nas regiões Norte. Até o dia 31 de maio, 13 favelas haviam registrado casos de Covid-19, totalizando 226 mortes. Na época, este número era maior do que os registros em 15 estados brasileiros. (Sardinha, Botelho, \& Carvalho, 2020).

As vulnerabilizações que a população negra sofre são sustentadas historicamente. Quando associadas à pandemia de um vírus com alto grau de contágio, essas vulnerabili-

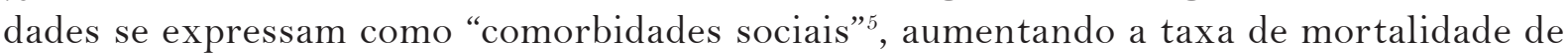


alguns grupos específicos. A comorbidade justificaria, em tese, maior cuidado quanto à possibilidade do contágio, ou adoção de medidas de proteção com uma maior intensidade. É neste sentido que a máscara aparece como importante meio de proteção, entre outras medidas individuais.

No entanto, o racismo enquanto organizador estrutural da sociedade não reproduz opressões apenas em situações institucionais através da falência provocada dos aparatos públicos de saúde e segurança sanitária. A evidência do racismo estrutural é ser capaz de replicar suas opressões em outros níveis, inclusive no uso de máscaras pelos corpos negros.

\title{
Do corpo perigoso ao corpo matável
}

\begin{abstract}
"Domingo meio-dia, estoura um assalto a loja, do meu lado. Meto o pé correndo. Por um segundo, minha reação: tirar a máscara pra ninguém achar que foi eu. Que inferno!"
\end{abstract}

(Roger Cipó via instagram @rogercipo)

Bruno Latour, em seu texto "Como falar do corpo", elabora a construção de uma epistemologia política usando o corpo como metáfora. O autor propõe que o corpo seja lido como a capacidade de ser afetado, a "trajetória dinâmica através do qual aprendemos a registrar e a ser sensíveis àquilo de que é feito o mundo" (Latour, 2008, p. 39). Ao mesmo tempo que o corpo se equipa de sensibilidade segundo o que o mundo propõe, ele cria um mundo sensível, capaz de ser sentido. Para exemplificar, o autor se utiliza de um treino de narizes em uma indústria de perfumes. Narizes sem treino e que pouco distinguem os odores recebem um kit com uma diversidade de fragrâncias sensivelmente distintas. Após uma semana de treinamento, esses narizes são capazes de discriminar habilmente o que sentem: "aprendeu a ter um nariz que lhe permite habitar num mundo odorífero amplamente diferenciado. As partes do corpo, portanto, são adquiridas progressivamente ao mesmo tempo que as contrapartidas do mundo vão sendo registadas de nova forma” (Latour, 2008, p. 40). Conclui então que "Adquirir um corpo é um empreendimento progressivo que produz simultaneamente um meio sensorial e um mundo sensível."

Precisamos falar de um corpo que foi aprendido pelo mundo sensível a ser visto como perigoso e agir em resposta a essa articulação. Um kit é entregue ao homem negro bem antes do nascer. O que ele sentirá a partir do seu corpo negro está sendo articulado desde o princípio do colonialismo, da escravização. É sustentado pela colonialidade ${ }^{6}$ e pelo progressivo genocídio do seu povo. Sentir medo ao usar a máscara é um aprendizado de um corpo constantemente ameaçado simplesmente por existir. "memórias vivas enterradas em nossa psique, prontas para serem contadas” (Kilomba, 2019, p. 33).

Kilomba (2019) evoca o que chama de máscara do silenciamento. Por séculos, o corpo negro foi obrigado por seus senhores a usar uma máscara para impedi-los de comer das plantações enquanto trabalhavam. "Ela era composta por um pedaço de metal colocado no interior da boca do sujeito negro, instalado entre a língua e o maxilar e fixado por detrás da cabeça por duas cordas, uma em torno do queixo e a outra em torno do nariz e da testa" (Kilomba, 2019, p. 33). Para o sujeito negro, a máscara traria silenciamento e medo, emudecendo o que era capaz de colocar palavras no mundo, através da tortura. 
Para o sujeito branco, a máscara reafirma a relação de outridade com o sujeito negro, a partir da representação do que o branco teme ser. Ladrão, violento, bandido.

Nesta relação de outridade, onde o "eu" é formado a partir da alteridade com o "outro", o sujeito branco cria o seu outro primordial no sujeito negro. Dentro das relações de poder já instituídas que concediam ao sujeito branco as "boas” representações de civilidade, racionalidade e comportamento, o sujeito negro será tomado como este outro selvagem, irracional, que precisa ter o corpo controlado. Assim será nas relações mais profundas da produção do sujeito. Enquanto o sujeito branco detém os privilégios de "ser", o sujeito negro só poderá ter uma experiência de si através do "não-ser". (Carneiro, 2005, Kilomba, 2019).

A relação de outridade estabelece no sujeito negro a personificação de todos os aspectos repressores que o sujeito branco constrói, "a representação mental daquilo com o que o sujeito branco não quer se parecer", e ela conclui dizendo que "não é com o sujeito negro que estamos lidando, mas com as fantasias brancas sobre o que a negritude deveria ser" (Kilomba, 2019, p. 38). Ainda que essas fantasias estejam localizadas no sujeito branco, ela reverbera também no sujeito negro, que este não consegue desenvolver uma relação consigo a não ser pela representação dada pelo sujeito branco. Sempre como o outro.

Esta fantasia é operada por máquinas que reafirmam a posição do sujeito negro no imaginário social branco, dentre elas os discursos científicos. Cesare Lombroso (1835 - 1909), médico italiano, expoente da criminologia positivista, tomando o cárcere como campo de pesquisa, sustenta um discurso racial a partir da sistematização do que poderiam ser sinais anatômicos associados à criminalidade. Amplamente difundidas, suas construções teóricas produziram estereótipos que balizaram o medo e ações de antecipação da sociedade aos "possíveis" criminosos, a fim de garantir controle social, o que se desdobraria em conceitos como a periculosidade - o quão naturalmente propenso a delitos um sujeito está - e a individualização da pena, indicando que sujeitos com alta periculosidade precisam de penas específicas para superar sua propensão delitiva. Ambos os conceitos estão em articulação ao direito penal até hoje (Elbert, 2001, Goés, 2015). Lombroso vincularia ainda o que chamava de seres primitivos (os negros), selvagens e os criminosos natos à ausência de desenvolvimento cerebral completo, encontrado no homem branco. Essa pretensão europeia se difundiu amplamente, efeito da colonialidade (Quijano, 1992, 2005)

Apesar da teoria lombrosiana entrar em desuso no pensamento europeu, seus pensamentos se proliferaram em outros continentes, carregando o princípio e estereótipos racistas a regiões como a América Latina, onde seguramente encontraria uma concentração de povos 'degenerados' a serem controlados por uma suposta elite. Raimundo Nina Rodrigues, médico brasileiro, torna-se expoente lombrosiano, ao contestar o princípio de igualdade jurídica garantida na abolição da escravatura, e atribuir responsabilidade penal diferenciada para raças não-brancas. Ao fornecer legitimidade científica ao controle racial, "assegurou a manutenção da desigualdade racial e criminalização dos negros e seus descendentes" (Góes, 2015, p. 230).

A fantasia de uma sociedade construída a partir do medo branco $^{7}$, calcada em teorias racistas, reproduziu opressões raciais em diversos níveis. A subjetivação própria da colonialidade se manifesta na sustentação de hierarquias raciais mesmo após o colonialismo. Para isso, produz-se um sistema objetivo e a-histórico de discursos que subordinam todas as formas de vida à ocidentalizada (Quijano, 1992). Por conseguinte, produz-se no sujeito negro a internalização da inferioridade e da periculosidade. "Sou odiado por uma raça inteira" (Fanon, 2008, p. 118). 
Quando Almeida (2017) propõe que o racismo se capilariza de modo institucional e estrutural, indica que não é suficiente demonstrar de modo consciente a irracionalidade do racismo, justamente porque ele está sendo operado nos modos inconscientes, nas máquinas de subjetivação (Guattari \& Rolnik, 2012). Nos meios de reprodução de mídia, de comunicação, na economia, na organização da cidade, nos modos de distribuição de renda extra em tempos de crise, na disposição de aparatos públicos de saúde para a população. É a condição estruturante do racismo que o faz ser manifesto nas ações institucionais sem que seja percebido como opressão ou violência, sobretudo em políticas públicas que ensejam garantir saúde e segurança aos mais pobres ou em medidas de segurança sanitária.

A irracional abrangência do racismo pode fazer com que negros internalizem a visível cisão racial da sociedade com normalidade, inclusive as representações da negritude a partir da visão do sujeito branco. Veiga (2019) indica que essa internalização não é trivial, mas um processo de violência e culpa de si, um direcionamento do ódio branco para o próprio corpo, o auto-ódio.

A experiência da negritude é marcada pelo desprezo e pelo ódio que a branquitude projetou sobre as vidas negras desde a escravidão até os dias de hoje. Ódio que, introjetado nas subjetividades negras, resulta num doloroso processo de auto-ódio. (Veiga, 2019, p. 246)

Ao trazer o corpo a partir das ferramentas latourianas, como uma interface de contato entre o que sente e o sensível em articulação, indicamos que assim o é com a experiência da negritude. Através da marca que seu corpo carrega, na mielinização da sua pele, na textura dos seus cabelos, nos traços fenotípicos ou culturais, sente e percebe o mundo sensível ao racismo em articulação, sendo esta experiência marcada pela rejeição na simples aparição, banindo-lhe do direito de não pensar, a todo momento, com a identidade que lhe será imputada (Souza, 1983). Para Fanon (2008), o complexo de inferioridade a partir do processo de outridade, da internalização das representações da negritude provindos de um imaginário social branco, se dão em dois processos. Inicialmente econômicos, seguidos de uma epidermização dessa inferioridade.

No mundo branco, o homem de cor encontra dificuldades na elaboração de seu esquema corporal. $\mathrm{O}$ conhecimento do corpo é unicamente uma atividade de negação. É um conhecimento em terceira pessoa. Em torno do corpo reina uma atmosfera densa de incertezas... Lenta construção de meu eu enquanto corpo, no seio de um mundo espacial e temporal, tal parece ser o esquema. Este não se impõe a mim, é mais uma estruturação definitiva do eu e do mundo - definitiva, pois entre meu corpo e o mundo se estabelece uma dialética efetiva. (Fanon, 2008, p. 104)

É esse esquema epidérmico racial que anuncia ao corpo negro o perigo que corre no mundo branco. No dia 28 de novembro de 2019, Gilberto Porcidonio, através de seu perfil na rede social Twitter, fez uma pergunta: "Se o racismo acabasse hoje, o que você faria?". Ele mesmo, a título de exemplo de resposta, disse: "Eu iria ao shopping de chinelo fácil". A thread ${ }^{8}$ alcançou 55 mil curtidas até maio de 2020, e foi respondida com mensagens, tais como "teria um filho"; "Abriria minha bolsa dentro da loja"; "Correria na rua com tranquilidade"; "Usaria o capuz do meu casaco"; "pegaria meu celular dentro da bolsa dentro da loja, e não antes de entrar na loja"; "me sentiria protegida na presença da polícia". 
Com isso, o ímpeto de tirar a máscara em uma situação de possível conflito policial não é trivial ou isolada. Acompanham afetos de proteção a uma certa realidade vivida pelo estudante Carlos, impedido de permanecer em um centro comercial por usar máscara (Agência $O$ Globo, 2020); pelo repórter Manoel Soares, que teve uma foto com máscara publicada em uma rede social e recebeu comentários como "Esse preto de máscara, Assalto?” (Folha, 2020). Para o homem negro, a máscara, que deveria trazer proteção, acoplada ao seu corpo, produz como efeito a reatualização do imaginário social constituído historicamente. O agravo é que tal imaginário social não produz no corpo negro somente o senso de proteção ao racismo. O medo da máscara é o medo da morte literal.

$\mathrm{O}$ assassinato de pessoas negras, sobretudo homens negros, de modo violento se acentua a cada ano. Segundo o Atlas da Violência (Cerqueira et al., 2019), em 2017, 75,5\% das vítimas de homicídios foram negros. Afirmamos no decorrer do artigo uma certa experiência do corpo negro, no entanto o gênero precisa ser delimitado especificamente neste contexto, onde $91 \%$ dos homicídios no Brasil são de homens, destes $63 \%$ são de jovens entre 15 a 29 anos.

Apenas esses dados já demonstram que há algo que aproxima o homem negro dos homicídios, o que ganha intensidade quando nos deparamos com alguns casos recorrentes onde um homem negro é morto por estar em atividade considerada suspeita ao manusear um objeto aparentemente "neutro". É o caso de Rodrigo, morto por usar um guarda chuva confundido por um fuzil (Moura, 2018). De Alan e Gleberson, mortos enquanto andavam de moto carregando uma peça da moto de um deles (Soares, 2014), e de Hélio, morto enquanto instalava um toldo com sua furadeira $(G 1,2010)$. Soma-se a isso os requintes de violência e crueldade, quando da morte de Evaldo e Luciano, que tiveram o carro em que estavam alvejado por 80 tiros de militares do exército "por engano" (Juca, 2019): e da chacina de Costa Barros, onde Wilton, Wesley, Cleiton, Carlos Eduardo e Roberto, mortos dentro de um carro por 111 tiros disparados por policiais militares (Martin, 2016).

Todos corpos de homens negros, que tiveram as razões de suas mortes transferidas aos objetos de que faziam uso, forjando o racismo e a política de morte que atravessam o corpo do homem negro. Após uma política assimilacionista, iniciada no "mito da democracia racial" e na sustentação histórica da imagem de um país que não possui problemas raciais (Góes, 2017), não é admissível que o preconceito racial incentive tais mortes, é necessário que um objeto absorva a matabilidade do corpo negro. São mortes que avisam ao corpo negro o perigo que corre por ele mesmo ser lido como o perigo. É este o medo que a máscara, em articulação com o corpo do homem negro e com o mundo que funciona por uma política de morte ao negro, sinaliza e faz sentir. "Que dia para usar máscara”, “Tire a máscara. Que Inferno!”.

Lisboa indica que "alguns corpos acabam sendo mais mortificados e mais mortificáveis que outros. Corpos que, sob a relação policialesca, são passíveis de violência, utilizada como forma de contenção e legitimada pela pedagogia do medo." (Lisboa, 2018, p. 90). Para Góes (2017), há a partir da política de "guerra às drogas" um extermínio em curso, onde uma sequência de violências e execuções é justificada pelo estado, que assume o papel ostensivo em seu combate. Nesse sentido, os autores concluem que negros, em especial os homens negros, são tomados como inimigos do Estado (Góes, 2017; Lisboa, 2018).

O extermínio, no entanto, não se resume a essa mortificação literal, mas está atrelado também a todas as vulnerabilizações já citadas neste artigo, traduzindo-se como uma política. Esta política de morte foi nomeada por Mbembe (2018) como necropolítica. O filósofo camaronês articula em que medida o poder soberano se sustenta a partir da 
operacionalização da vida através da morte. A morte já não vista como um limite, mas algo a ser gerido pela política a partir do momento em que a soberania não se restringe ao controle territorial, configurando-se como a exploração do direito de matar. Mbembe analisa a função do racismo como o que distribui a aceitabilidade de fazer morrer. Para isso, seria necessário um estado permanente de exceção, experimentado pelos campos de concentração a partir de um olhar direcionado ao mundo europeu, mas amplamente encontrado e pouco discutido nos países colonizados: "O lugar em que a soberania consiste fundamentalmente no exercício de um poder à margem da lei (ab legibus solutus) e no qual tipicamente a "paz" assume a face de uma "guerra sem fim” (Mbembe, 2018, p. 132).

Entender a marca colonial do Brasil é entender que a exceção nos marca enquanto nação, nossas práticas, traços e linguagem. Dizer que nos constituímos desde sempre numa exceção é perceber que as nações que passaram pelo processo de colonização "acabaram por configurar tanto territórios quanto práticas sociais, principalmente nos espaços onde estão as populações negras, racializadas e podres nos contextos de colonialidade" (Lima, 2018 p. 27). Territórios onde se legitimam as ações policiais, onde se incentiva a invisibilidade dos dados, a precarização da saúde e o descaso como projeto político.

\section{Considerações finais: o novo normal não tem nada de novo}

"Pior que eu já morri tantas antes de você me encher de bala"

(Mandume, canção por Emicida)

Muitos pensadores indicam disrupções próprias ao viver uma pandemia. Nossa relação com o mundo mudou e certamente mudará. As próprias medidas sanitárias de segurança e proteção são práticas a serem cada vez mais adotadas, a exemplo de alguns países asiáticos que já utilizam máscaras com certa naturalidade no dia a dia. No entanto, como apontado, tais medidas, ao se articularem a determinados corpos - os corpos dos homens negros - podem ter como efeito não a proteção, mas mais vulnerabilização e, até mesmo, medo e morte.

O genocídio da população negra é experienciado não somente pelas mortes violentas, mas por todas as desigualdades e dificuldades de acesso a educação, saúde, saneamento e moradia, limitando o povo negro a posições subalternas, efeitos de uma racionalidade colonial capaz de fazer com que a população negra internalize essa cisão racial visível com normalidade. A assimetria no acesso aos aparatos públicos de saúde em tempos de pandemia é mais uma prática que faz e deixa morrer. Medidas individuais de proteção e prevenção ao contágio, para a população negra, acabam se tornando a alternativa viável para garantir segurança em tempos de pandemia, reafirmando uma subjetividade neoliberal, agente de si até mesmo na proteção. A máscara, item cada vez mais reafirmado como importante meio de prevenção à Covid-19, é vista com neutralidade até se articular com corpos racializados.

A racialização dos corpos na América Latina produziu o corpo negro como a representação do que está à margem - selvagem, perigoso. O racismo, ao ser internalizado pelo sujeito negro, também produz um corpo que é constantemente afetado pela violência 
e pelo ódio a ele direcionado, tentanto negá-la ou dele se protegendo. Apontar o medo de usar máscara num ato de proteção ao racismo, em detrimento a proteção ao contágio, torna o racismo obsceno.

Assim, a política de morte própria dos países colonizados é reafirmada em meio à pandemia: "O racismo consiste em fazer de toda tragédia que ele provoca, um acidente. Em inscrever constantemente a vida do sujeito racializado em uma série infinita de acidentes que não cessam de se repetir" (Mbembe, 2020, p. 3). Se há algum tipo de sensibilidade proposta pelo mundo ao corpo negro, é o medo desse acidente se repetir.

O diagrama de morte, que se desenha em sociedades coloniais, puxa o corpo racializado para sua matabilidade. Este corpo congrega em si diversas "comorbidades sociais" mantidas politicamente, seja a partir de um sistema de saúde público em situação de colapso e precarizado antes mesmo de uma pandemia acontecer, seja pela política de segurança pública. O racismo, motor dessa necropolítica, é o que faz com que até mesmo nos usos de objetos de segurança sanitária, simples máscaras para cobrir a região da mucosa, a possibilidade do morrer se evidencie. Cabe a esse corpo se articular então com dois perigos: do contágio e do racismo.

No início da pandemia, havia uma especulação pessimista quanto ao controle do contágio de Covid-19 em países latinos e africanos. As preocupações em torno das desigualdades e precarizações experienciadas nesses espaços preocupavam órgãos supranacionais. No entanto, Galindo (2020) é precisa ao indicar que, por aqui, países latino americanos, colonizados e sofrendo as investidas neoliberais por todos os lados, " a sentença de morte estava escrita antes do coronavírus chegar em um avião de turismo.” (p. 124).

\section{Notas}

1 A cena apresentada foi vivenciada por um dos autores do artigo e serviu como disparador para a discussão.

2 Partimos da consideração de que o campo psicossocial não pode ser explicado apenas pelas interações dos humanos entre si, mas antes emerge como efeito heterogêneo de agenciamentos entre atores humanos e não humanos, daí optarmos pelo termo sócio-técnico. (Latour, 2006)

3 As organizações multilaterais também contribuem para a reprodução da colonialidade e da lógica moderno-colonial que marca vidas como humanas e não-humanas a partir do momento em que difundem a lógica ocidentalizada alicerçante dos saberes biomédicos hegemônicos. (Castro Gómez \& Grosfoguel, 2007)

4. Sardinha, L., Botelho, P., \& Carvalho, M. V. (2020). Desigualdades raciais em tempos de pandemia na cidade do Rio de Janeiro: reflexões a partir de 1918 e 2020 (no prelo) 
5 Comorbidade tem seu sentido atribuído pela áreas da saúde como uma associação entre duas ou mais patologias em um sentido intensificador. Neste texto, estendemos o seu sentido, adjetivando-a como social a fim de apontar que situações não necessariamente patológicas do corpo podem se associar com alguma patologia, intensificando-a.

6 Quijano (1992) distingue colonialismo como "o estabelecimento de uma relação de dominação direta, política, social e cultural, dos europeus sobre os conquistados de todos os continentes" (p. 1) e a colonialidade como a continuação dessa dominação após a extinção do colonialismo. A colonialidade se sustenta a partir da relação hierarquizante entre um domínio ocidental estadunidense e eurocêntrico sustentado pela hierarquização de máquinas subjetivantes. Para ler mais, Quijano (1992, 2005).

7 Refere-se ao medo das elites brasileiras de perderem o controle da situação racial do país decorrida pós-abolição, a exemplo da revolução haitiana, caracterizado pelas diversas políticas adotadas, visando constranger práticas ligadas a sujeitos racializados, no que foi chamado infrações sem vítimas (Góes, 2015).

8 A tradução literal seria fio, utilizada no microblog no sentido de um fio de postagens gerado a partir de mensagens seguidas. A história contada nessa sequência de mensagens é a thread.

\section{Referências}

Agência $O$ Globo, (2020, 09 de abril). Estudante que usava máscara contra Covid-19 acusa de racismo segurança de loja. Ig. Recuperado de https://ultimosegundo.ig.com.br/brasil/2020-04-09/estudante-que-usava-mascara-contra-covid-19-acusa-de-racismo-seguranca-de-loja.html

Almeida, S. (2017). Racismo estrutural. São Paulo Pólen Produção.

ANVISA. (2020). Orientações Gerais - Máscaras faciais de uso não profissional. Recuperado de $\quad$ http://portal.anvisa.gov.br/documents/219201/4340788/NT+M\%C3\%A 1scaras.pdf/ bf430184-8550-42cb-a975-1d5e1c5a10f7

Batista, A. et al. (2020). Análise socioeconômica da taxa de letalidade da COVID-19 no Brasil. Rio de janeiro: Núcleo de Operações e Inteligência em Saúde (NOIS); PUC-RJ.

Carneiro, A. S. (2005). A construção do outro como não-ser como fundamento do ser. Tese de Doutorado, Programa de Pós-graduação em Educação, Universidade de São Paulo, São Paulo.

Castro Gómez, S. \& Grosfoguel, R. (2007). Prólogo. Giro decolonial, teoría crítica y pensamiento heterárquico. In El giro decolonial: reflexiones para una diversidad epistémica más allá del capitalismo global (pp. 09-23). Bogotá: Siglo del Hombre Editores; Universidad Central, Instituto de Estudios Sociales Contemporáneos y Pontificia Universidad Javeriana, Instituto Pensar.

Cerqueira, D. et al. (2019). Atlas da violência 2018. Rio de janeiro: Instituto de Pesquisa Economica Aplicada; Fórum Brasileiro de Segurança Pública. 
Costa, C. L. J. (2020). Pandemia do coronavírus e o seu impacto na população negra. In C. B. Augusto \& R. D. Santos (Orgs.), Pandemias e pandemônio no Brasil (pp. 279-287). São Paulo. Tirant lo Blanch..

Dardot, P. \& Laval, C. (2016). A nova razão do mundo. São Paulo: Boitempo.

Elbert, C. A. (2001). Manual básico de criminología. Buenos Aires: Eudeba.

Fanon, F. (2008). Pele negra, máscaras brancas. Salvador: SciELO-EDUFBA.

Folha. (2020, 09 de maio). Repórter da Globo é alvo de racismo ao usar máscara: Não vou dar audiência'. Recuperado de https://f5.folha.uol.com.br/televisao/2020/05/reporter-da-globo-e-alvo-de-racismo-ao-usar-mascara-nao-vou-dar-audiencia.shtml

G1. (2010, 19 de maio). Homem é morto ao ter furadeira confundida com arma. Recuperado de http://g1.globo.com/brasil/noticia/2010/05/homem-e-morto-ao-ter-furadeira-confundida-com-arma.html

Gaglione, C. (2020, 20 de março). A procura por álcool em gel. E como ele age contra o coronavírus. Nexo Jornal. Recuperado de https://www.nexojornal.com.br/expresso/2020/03/20/A-procura-por-\%C3\%A 1lcool-em-gel.-E-como-ele-age-contra-o-coronav\%C3\%ADrus

Galindo, M. (2020). Desobediencia, por tu culpa voy a sobrevivir. In P. Amadeo (Org.), Sopa de Wuhan (pp. 119-128). Buenos Aires: Aspo Editorial,

Guattari, F. \& Rolnik, S. (2012). Micropolítica: cartografias do desejo. Petrópolis, RJ: Vozes.

Góes, L. (2015). A "tradução" do paradigma etiológico de criminologia no Brasil: Um diálogo entre Cesare Lombroso e Nina Rodrigues da perspectiva Centro-Margem. Dissertação de Mestrado, Programa de Pós-graduação em Direito, Universidade Federal de Santa Catarina, Florianópolis, SC.

Góes, L. (2017). Pátria exterminadora: O projeto genocida brasileiro. Revista Transgressões: Ciências criminais em debate, 5(2), 53-79.

Howard, J. et al. (2020). Face masks against COVID-19: an evidence review. Recuperado de https://www.preprints.org/manuscript/202004.0203/v1

IBGE. (2019). Pesquisa Nacional por Amostra de Domicílios Contínua 2012/2019. Recuperado de https://biblioteca.ibge.gov.br/visualizacao/livros/liv101707 informativo.pdf

Juca, B. (2019, 10 de maio). Doze militares são denunciados por fuzilamento de músico e catador no Rio El Pais. Recuperado de https://brasil.elpais.com/brasil/2019/05/11/politica/1557530968 201479.html

Kilomba, G. (2019). Memórias da plantação: episódios de racismo cotidiano. Rio de Janeiro: Editora Cobogó.

Latour, B. (2006). Changer se societé - refaire de da Sociologie. Paris: La Découverte.

Latour, B. (2008). Como falar do corpo? A dimensão normativa dos estudos sobre a ciência. In R. Roque (Org.), Objectos impuros: experiências em estudos sobre a ciência (pp. 39-61). Porto: Afrontamento.

Latour, B., Rifiotis, T., Petry, D. F., \& Segata, J. (2015). Faturas/fraturas: da noção de rede à noção de vínculo. Ilha Revista de Antropologia, 17(2), 123-146.

Lima, F. (2018). Bio-necropolítica: diálogos entre Michel Foucault e Achille Mbembe. Arquivos Brasileiros de Psicologia, 70 (n.spe), 20-33. 
Lisboa, F. A. (2018). Do conflito com a lei ou da lei em conflito? Na privação de liberdade, outro estatuto (re)existe. Dissertação de Mestrado. Programa de Pós-graduação em Psicologia, Universidade Federal do Rio de Janeiro, RJ.

Martin, M. (2016, 25 de dezembro). O eco dos 111 tiros de Costa Barros. El Pais. Recuperado de https://brasil.elpais.com/brasil/2016/11/28/politica/1480370686 545342.html

Mbembe, A. (2018). Necropolítica. São Paulo: N-1 edições.

Mbembe, A. (2020). O racismo anti-negro funciona da mesma maneira que um virus. Recuperado de https://n-1edicoes.org/093

Moura, C. (2018, 19 de setembro). PM confunde guarda-chuva com fuzil e mata garçom no Rio, afirmam testemunhas El Pais. Recuperado de https://brasil.elpais.com/brasil/2018/09/19/ politica/1537367458 048104.html

Organizações das Nações Unidas - ONU. (2017, 5 de dezembro). Quase 80\% da população brasileira que depende do SUS se autodeclara negra. Rio de janeiro: Autor. Recuperado de https://nacoesunidas.org/quase-80-da-populacao-brasileira-que-depende-do-sus-se-autodeclara-negra/\#: :text $=$ Quase\%2080\%25\%20da\%20popula\%C3\%A 7\%C3\%A30\%20brasileira\%20que\%20depende\%20do\%20Sistema\%20\%C3\%9Anico,negra\%20(preta\%20e\%20parda).

Preciado, P. (2020). Aprendendo com o Virús. Recuperado de http://agbcampinas.com.br/ site/2020/paul-b-preciado-aprendendo-com-o-virus/

Quijano, A. (1992). Colonialidad y Modernidad-racionalidad. In H. Bonillo (Org.), Los conquistados (pp. 437-449). Bogotá: Tercer Mundo Ediciones; FLACSO.

Quijano, A. (2005). Colonialidade do poder, Eurocentrismo e América Latina. In E. Lander, (Org.), A colonialidade do saber: eurocentrismo e ciências sociais. Perspectivas latino-americanas (pp. 117-142). Buenos Aires: CLACSO.

Rose, N. S. (2019). Our psyquiatric future: the politics of mental health. Cambridge, NY: Polity Press. Síntese. (2018). Uma análise das condições de vida da população brasileira: 2018. Rio de Janeiro. IBGE. Recuperado de https://biblioteca.ibge.gov.br/visualizacao/livros/liv101629.pdf

Soares, R. (2014, 19 de fevereiro). Imagens mostram momento em que mototaxistas são mortos por PMs em Rocha Miranda Extra. Recuperado de https://extra.globo.com/casos-de-policia/imagens-mostram-momento-em-que-mototaxistas-sao-mortos-por-pms-em-rocha-miranda-1 1645919.html

Souza, N. S. (1983). Tornar-se negro: as vicissitudes da identidade do negro brasileiro em ascensão social. Rio de Janeiro: Edições Graal.

Stutt Rojh, Retkute, R., Bradley, M., Gilligan, C. A., \& Colvin, J. (2020) A modelling framework to assess the likely effectiveness of facemasks in combination with 'lock-down' in managing the COVID-19 pandemic. Procedings Royal Society, 476, 1-2 1. 20200376. http://dx.doi. org/10.1098/rspa.2020.0376

Veiga, L. M. (2019). Descolonizando a psicologia: notas para uma Psicologia Preta. Fractal: Revista de Psicologia, 31(nspe.), 244-248. 


\section{LUCAS GABRIEL DE MATOS SANTOS}

https://orcid.org/0000-0002-5803-0996

Doutorando em Psicologia pelo Programa de Pós-graduação em Psicologia da Universidade Federal do Rio de Janeiro, RJ.

Endereço: Rua Ibituruna, 126, Rio de Janeiro, RJ, CEP 20271020.

E-mail: lucasgabrieldematos@gmail.com

\section{ROSA PEDRO}

https://orcid.org/0000-0002-3476-790X

Professora titular do Instituto de Psicologia da Universidade Federal do Rio de Janeiro, RJ.

E-mail: rosapedro@globo.com

\begin{tabular}{|l|l|}
\hline \multirow{2}{*}{ Histórico } & $\begin{array}{l}\text { Sulbmissão: 30/06/2020 } \\
\text { Revisão: 24/07/2020 } \\
\text { Aceite: 27/07/2020 }\end{array}$ \\
\hline $\begin{array}{l}\text { Concepção: L.G. } \\
\text { Coleta de dados: L.G. } \\
\text { dos autores }\end{array}$ & $\begin{array}{l}\text { Análise de dados: L.G.; R.P. } \\
\text { Elaboração do manuscrito: L.G.; R.P. } \\
\text { Revisões críticas de conteúdo intelectual importante: R.P. } \\
\text { Aprovação final do manuscrito: L.G.; R.P. }\end{array}$ \\
\hline $\begin{array}{l}\text { Consentimento } \\
\text { de uso de imagem }\end{array}$ & \begin{tabular}{l} 
Não se aplica. \\
\hline $\begin{array}{l}\text { Aprovação, ética } \\
\text { e consentimento }\end{array}$
\end{tabular} \\
\hline $\begin{array}{l}\text { Financiamento } \\
\text { Não se aplica. }\end{array}$ \\
\hline
\end{tabular}

